\title{
Bone Marrow Adipocytes-Role in Physiology and Various Nutritional Conditions in Human and Animal Models
}

\author{
Katarzyna Piotrowska *(D) and Maciej Tarnowski (D) \\ Department of Physiology, Pomeranian Medical University in Szczecin, al. Powstancow Wlkp.72, \\ 70-111 Szczecin, Poland; maciejt@pum.edu.pl \\ * Correspondence: piot.kata@gmail.com or katarzyna.piotrowska@pum.edu.pl
}

check for updates

Citation: Piotrowska, K.; Tarnowski, M. Bone Marrow Adipocytes-Role in Physiology and Various Nutritional Conditions in Human and Animal Models. Nutrients 2021, 13, 1412. https://doi.org/10.3390/ nu13051412

Academic Editor: Roberto Iacone

Received: 30 March 2021

Accepted: 20 April 2021

Published: 22 April 2021

Publisher's Note: MDPI stays neutral with regard to jurisdictional claims in published maps and institutional affiliations.

Copyright: (c) 2021 by the authors. Licensee MDPI, Basel, Switzerland. This article is an open access article distributed under the terms and conditions of the Creative Commons Attribution (CC BY) license (https:/ / creativecommons.org/licenses/by/ $4.0 /)$.

\begin{abstract}
In recent years, adipose tissue has attracted a lot of attention. It is not only an energy reservoir but also plays important immune, paracrine and endocrine roles. BMAT (bone marrow adipose tissue) is a heterogeneous tissue, found mostly in the medullary canal of the long bones (tibia, femur and humerus), in the vertebrae and iliac crest. Adipogenesis in bone marrow cavities is a consequence of ageing or may accompany pathologies like diabetes mellitus type 1 (T1DM), T2DM, anorexia nervosa, oestrogen and growth hormone deficiencies or impaired haematopoiesis and osteoporosis. This paper focuses on studies concerning BMAT and its physiology in dietary interventions, like obesity in humans and high fat diet in rodent studies; and opposite: anorexia nervosa and calorie restriction in animal models.
\end{abstract}

Keywords: bone marrow adipose tissue; marrow fat; obesity; calorie restriction; dietary interventions; animal models

\section{Introduction}

In recent years, adipose tissue has attracted a lot of attention. It is not only an energy reservoir but also plays important immune, paracrine and endocrine roles [1,2]. Moreover, the rising incidence of worldwide obesity has increased the pace of research. Basically, adipose tissue has been classified into three types: white, brown (WAT and BAT, respectively) and beige adipose tissue. Since the mid-1990s, a third important adipose tissue has received increasing attention - the marrow fat (bone marrow adipose tissue-BMAT). Previously, this fattissue was considered a space filler of the bone marrow (BM) with an unknown origin or function. With further in-depth research, as well as the employment of novel experimental techniques such as lineage tracing, it is now acknowledged that BMAT originates from skeletal lineages, maintaining bone marrow homeostasis and influencing whole-body energy metabolism [3,4]. BMAT is a heterogeneous tissue, found mostly in the medullary canal of the long bones (tibia, femur and humerus), in the vertebrae and iliac crest. Haematopoiesis and osteogenesis are the processes responsible for the formation of bone marrow and bone, respectively. Adipogenesis in bone marrow cavities is a consequence of ageing or may accompany pathologies like diabetes mellitus type 1 (T1DM), T2DM, anorexia nervosa, oestrogen and growth hormone deficiencies or impaired haematopoiesis and osteoporosis.

\section{Types of Adipose Tissue}

Adipose tissue is distributed in distinct depots in the human body. Histologically it is characterised by the presence of adipocytes containing lipid filled vacuoles. Adipose tissue may be further differentiated, mostly based on its origin, function and molecular/biochemical features (reviewed in Li [5]) The subtypes of adipose tissue include WAT, BAT, beige or so-called 'brite' (brown/white) adipose tissue and MAT/BMAT. 


\subsection{White Adipose Tissue}

Mitochondria-sparse WAT is mostly located in the subcutaneous and visceral depots and functions as lipid storage, which is mobilised and liberates the free fatty acids from triglycerides in situations of energy demand. It constitutes $10-20 \%$ of body weight in lean humans [6]. When excess energy exists, lipogenic enzymes are stimulated to synthesise triglycerides for further use [7], while caloric intake restriction triggersthe release of free fatty acids from fat stores via enzymatic lipid hydrolysis into the blood stream [8]. Recent data show important differences between the two WAT depots, as visceral adipocytes are more responsive to lipolytic signals which upregulate the transport of free fatty acids, while subcutaneous adipocytes serve as stable energy reserves [9,10]. In periods of increased calorie intake, WAT expands through adipocyte hypertrophy (cell size increase) and hyperplasia (cell number increase), and terminal peroxisome proliferator-activated receptor delta (PPAR- $\gamma$ )- driven differentiation of adipocyte progenitors [10]. This expansion is especially significant in obese persons with metabolic syndrome, increased risk of T2DM or cardiometabolic disease [11].

Moreover, it plays an important role as a secretory organ, as it releases cholesterol, steroid hormones and vital molecules involved in immunological (immunomodulation) and endocrine processes, energy balance and regulation of food intake such as interleukin$6(\mathrm{IL}-6)$, adipokines or tumour necrosis factor- $\alpha(\mathrm{TNFa})$. Inflammatory molecule release may be also associated with macrophages infiltrating the tissue and with phagocytosing of dead adipocytes, which produces local inflammation that in future associates with the development of insulin resistance, particularly in obesity [12,13].

\subsection{Brown Adipose Tissue}

Brown adipocytes originate from myogenic lineage (dermomyotomes expressing MYF-5) [14]. BAT plays an important role in the control of body temperature. The main function of BAT is transfer energy from food into heat and the activity of this tissue is under the control of norepinephrine released from sympathetic nerves [15]. In foetuses and newborns, BAT, by intensive metabolism of fatty acids and expression of mitochondrial uncoupling protein 1 (UCP1), is responsible for heat production (thermogenesis). As the body develops, the presence of this tissue is limited and in adults it is barely detectable [16]. Some amount of cold-activated mitochondria-enriched BAT is present as discrete tissue deposits above the clavicle and in the subscapular region of the back [16-18]. Along with its role in adaptive thermogenesis, BAT seems to have an important role in regulating insulin resistance, protecting against obesity and diabetes $[5,9,19,20]$. BAT is inversely correlated with the body mass index [18].

Beige adipocytes (the'third' fat tissue) are an intermediate type of the above-mentioned adipocyte cell populations. They are mostly found in WAT depots and responds to stimuli like cold, the sympathetic nervous system (via catecholamines and $\beta$-adrenergic signalling), thyroid hormones or exercise. Beige adipocytes express UCP-1 protein at a lower level than brown adipocytes but are more sensitive to stimulation (reviewed in MartinezFernandez [20] and Chechi [21]).

The main subject of this review is, however, BMAT.

\subsection{Bone Marrow Adipose Tissue}

Presently, with the help of the recent advent of non-invasive methods to measure and analyse the marrow adipose tissue, the role of BMAT is receiving greater appreciation as it is a very important element of the marrow microenvironment, making up $50-70 \%$ of the marrow volume. This adipose tissue is also known as marrow adipose tissue (MAT) or yellow adipose tissue. It is an adipose depot with unique features distinguishing it from the better characterised extramedullary sites. It accounts for approximately $5-10 \%$ of the total fat mass in healthy, lean, adult humans (reviewed in Fazeli [22]). Application of MRI-based techniques demonstratesthat the amount of total BMAT in a skeleton of average size ranges from 0.5 to $3 \mathrm{~kg}$ [23]. 
Bone marrow adipocytes originate in the BM from mesenchymal stem cells (MSC). The key transcriptional factors, $\mathrm{PPAR} \gamma$ and $\mathrm{c} / \mathrm{EBP} \alpha$, control BM adipogenesis [9]. BM MSCs have the potential to differentiate towards osteoblasts, adipocytes or chondrocyte lineages [24-26]. PPAR $\gamma$ insufficiency in BM progenitor cells leads to osteoblastogenesis, which is considered a competitive process for adipogenesis [27]. The two processes are strictly and opposingly regulated. Factors that promote osteogenesis like mechanical forces, growth hormone or insulin-like growth factor 1 (IGF-1) limit adipogenesis and vice versa, pro-adipogenic stimuli like oxidative stress, immobilisation, elevated glucocorticoid levels limit osteoblastogenesis $[4,25,28]$. Thus, the BM MSCs shift towards either lineage results from a complex interplay of systemic and local mediators.

For many years, this tissue was considered as only a filler of trabecular bone cavities (ribs, sternum, vertebrae) and the medullary canal of long bones (tibia, femur, humerus) involved in the transition of red (haematopoietic) bone marrow to yellow (non-haematopoietic) bone marrow. It gradually accumulates in areas of trabecular bone of the femur, tibia and vertebrae and fills the entire marrow cavity by the third decade of human life [22,28], with males demonstrating greater amounts of BMAT compared to females [29]. In the red marrow, where haematopoiesis and bone remodelling are active, adipocytes are less frequent and account for up to $45 \%$ of the marrow, while in the yellow marrow, where haematopoiesis is almost absent, adipocytes are densely packed and fill up to $90 \%$ of the marrow compartment [5]. It has also been shown that enlargement of this compartment accompanies metabolic diseases, states of increased bone fragility and obesity [30].

Histologically, BMAT resembles white adipocytes, however it is a heterogeneous population of cells with distinct metabolisms and lipid compositions that, with ageing, gradually replaces the nucleus with lipid droplets [31]. The lipid content of BMAT, which is composed of saturated, monounsaturated and polyunsaturated fat, is used mostly as an energy source for populations of osteoblasts, osteoclasts and haematopoietic cells [32].

What is interesting is that BMAT expresses brown adipocyte gene markers (Prdm16, Dio2 and PGC1a), which decrease with ageing and diabetes [33]. Further studies have evidenced that BMAT has a mixed BAT/WAT phenotype. When bone marrow adipocytes were treated with triiodothyronine or a thyroid hormone receptor beta-specific agonist (GC-1) or rosiglitazone, a synthetic agonist for adipocyte-specific PPAR $\gamma$ and a potent insulin sensitiser significantly increased both BAT (Ucp1, Pgc1 $\alpha$, Dio2, $\beta 3 A R, \operatorname{Prdm} 16$ and FoxC2) and WAT (Adipoq and Lep) markers [33-35].

In both rodents and humans, two distinct subtypes of BM adipocytes have been described: constitutive BMAT (cBMAT/cMAT) and regulated BMAT (rBMAT/rMAT) [35]. $\mathrm{rBMAT} / \mathrm{rMAT}$ is present within active haematopoietic sites such as the mid- to proximal tibia, femur and lumbar vertebrae and develops throughout life. cBMAT/cMAT is located in the distal tibia and caudal vertebrae and develops rapidly after birth [35]. There are some important differences between these two populations: compared with cBMAT/cMAT adipocytes, rBMAT/rMAT adipocytes contain more saturated fatty acids and express lower levels of the adipogenic transcription factors Cebpa and Cebpb, similar to WAT [35].

Furthermore, their response to physiological stress differs: rBMAT/rMAT adipocytes reduce in size and number after cold exposition [35], fasting [36] or prolonged exercise [37]. Additionally, the size of rBMAT/rMAT cells increases with ageing, a high fat diet, caloric restriction and anorexia, irradiation, or treatments with hypoglycaemic thiazolidinediones (insulin-mimetic drugs used for type 2 diabetes treatment) and hyperglycaemia-causing glucocorticoids [38,39]. Conversely, cBMAT/cMAT changes in size in response to external stimuli or pathophysiological changes are less evident [26,35].

\section{BMAT-Function}

The exact function of BMAT remains unclear. When WAT capacity is exhausted, ectopic fat accumulation in other tissue as liver is found, and is regulated by insulin and responds to the energy balance in the body. BMAT is enclosed in cavities of the skeleton and also responds to insulin signalling-triggering molecules (i.e., rosiglitazone, a 
thiazolidinedione) [40]. As BMAT adipocytes are situated in a unique microenvironment, surrounded by haematopoietic and skeletal lineage cells, this likely contributes to its differential regulation and points to the local microenvironment, in addition to endocrine mediators, as major regulators of BMAT function.

As previously mentioned, both calorie restriction (CR) $[2,41]$ and high fat diets (HFD) anorexia nervosa [38] can increase skeletal BMAT in mice and humans. Research suggests that increased BMAT during calorie restriction is a result of adipogenesis and an increase of adipocyte number rather than an increase in adipocyte size; this may cause uncoupling between BMAT and energy metabolism [2]. Experiments on a mouse model of T1DM indicate that hypoinsulinaemia is insufficient to stop BMAT accumulation [42]. This may indicate different functions of adipocytes in BMAT: while some cells are connected with systemic energy demands, other may be responsible for supporting neighbouring cells.

\subsection{BMAT and Haematopoiesis}

The supporting function, both mechanical and biochemical, of BMAT adipocytes may be envisioned by certain examples. There are data showing BMAT's contribution to the mechanical properties of the skeleton or its association with haematopoiesis [43-45]. In vitro experiments showed increased differentiation of CD34+ cells in the presence of human BMAT and in the same context, in vivo results showed inhibitory characteristics of BMAT, induction of quiescence and loss of haematopoietic progenitor cells [43,46]. Inhibition of BMAT expansion improved haematopoietic engraftment and recovery in an experiment with marrow transplant after bone marrow irradiation in mice [46]. On the other hand, thiazolidinedione (TZD)-induced BMAT overgrowth did not cause a change in progenitor cell number in bone marrow in mice [47]. The latter may be explained by the existence of more complex regulatory loops when PPARs are activated. Furthermore, BMAT may serve as a certain source of cytokines, as discussed later and thus, influenceshaematopoiesis [48]. BMAT may protect osteoblasts from lipotoxicity, by creating a storage space for ectopic lipids [49]. During triglyceride excess, liver and skeletal muscle also store high amounts of lipids [50]. Cells of BMAT harvested from healthy animals show expression of transcription factors connected to adipogenesis: Pparg, Cebpa, Cebpbin [43,51].

\subsection{Cytokine Production}

Research on human adipocytes derived from sternal bone marrow stem cells (BMSCs) show secretion of cytokines IL-6, MIP-1 $\alpha$, G-CSF, and GM-CSF [52]. Adipocytes from the human iliac crest also secreted IL-6 and G-CSF and additionally, IL-8 after seven-days ceiling culture [43].

In a study by Laharrague, it was noted that primary culture of medullary adipocytes, secrete low amounts of IL-1 beta and TNF-alpha, but they secrete significant and regulated levels of IL-6 [53]. Murine BMSC-derived adipocytes produceCXCL1 and CXCL2 [54]. Moreover, genes encoding for IL-6, IL-1 $\beta$ and TNFa were found to be highly expressed in mouse $\mathrm{BM}$ adipocytes when compared to epididymal adipocytes, and what is interesting is that the expression of some of these factors was reduced with age [55]. A recent study showed that inflammatory cytokine levels were increased in visceral adipocytes, in high fat-induced obese mice, but BMAT did not exhibit a pro-inflammatory phenotype [56]. Cytokines produced in vitro and ex vivo are shown in Figure 1.

Osteoclast differentiation and activation are stimulated by cytokine secretion and it may seem that the cytokines released from BMAT may be greatly involved in the process $[57,58]$. Thus, BMAT may havean important role in bone remodelling by contributing to bone loss in osteoporosis and bone destruction during skeletal metastasis [57-59]. Adipocytes derived from BMAT also secrete adiponectin (explants of BMAT) and leptin (in vitroisolated cells) [43,53]. Adiponectin promotes insulin sensitivity, fat oxidation and anti-inflammatory action. The main source of adiponectin in normal conditions is WAT. However, during CR, expanding BMAT becomes an additional source of increased adiponectin level [60]. 


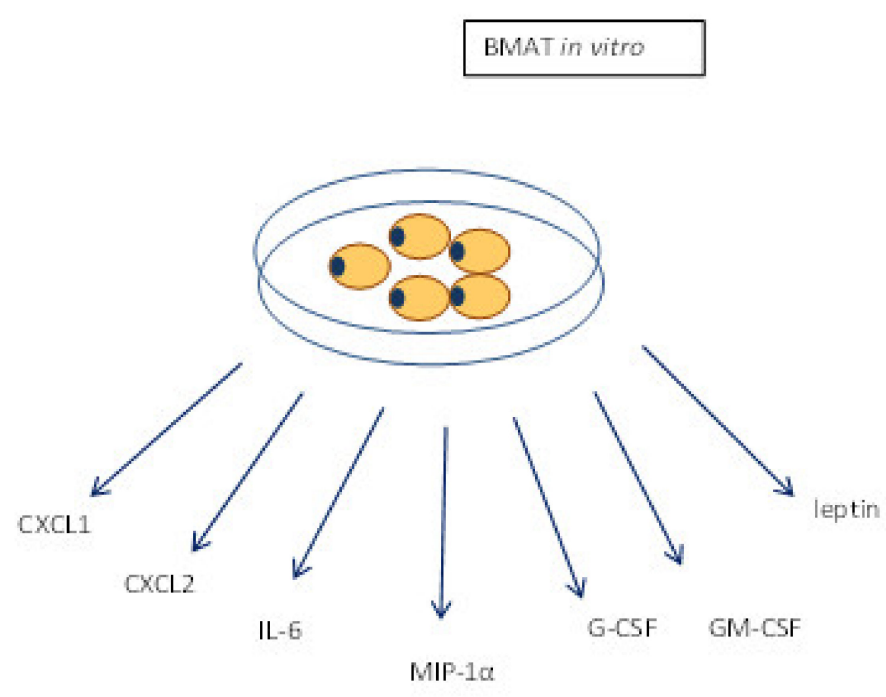

BMAT ex vivo

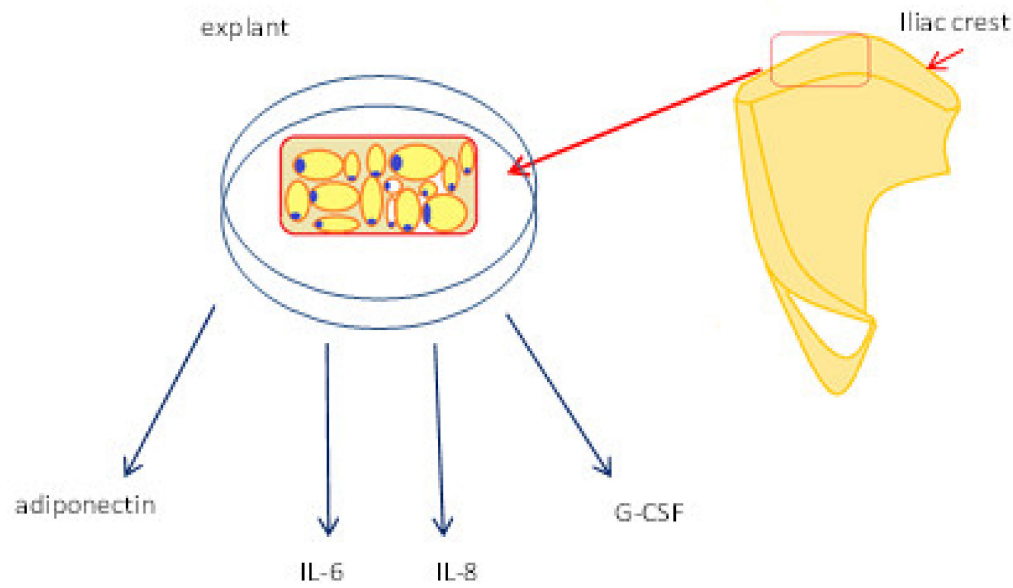

Figure 1. BMAT secretion of cytokines in different experimental protocols (extracted cells or whole tissue explants-without separation of single adipocytes). CXCL1-chemokine (C-X-C motif) ligand 1; CXCL2 - chemokine (C-X-C motif) ligand 2; G-CSF-granulocyte colony-stimulating factor; GMCSF-granulocyte-macrophage colony-stimulating factor; IL-6- interleukin 6; IL-8-interleukin 8; MIP-1 $\alpha$-macrophage inflammatory protein alpha.

\subsection{BMAT and the Endocrine System}

BMAT quantity changes in metabolic diseases like diabetes, ovarian dysfunctions, obesity and anorexia nervosa (Table 1). BMAT formation is influenced by endocrine factors (growth hormone, oestrogens, glucocorticoids) and is prone to endocrine modification. Depending on the metabolic context, the BMAT compartment may be either increased or decreased.Pituitary-derived growth hormone reduces BMAT formation [61]. The experimental removal of rats' pituitary glands caused a massive increase of BMAT that was reversed by the administration of somatotropin, but parathormone (PTH), 17 $\beta$-oestradiol or IGF-1 were not effective [61]. A decreased oestrogen level found in postmenopausal women or in experimental ovariectomy in animal models, FGF-21 and increased level of glucocorticoids also contribute to BMAT expansion [62-65]. BMAT accumulation may be the result of glucocorticoid increases during CR and short-term transdermal oestro- 
gen administration diminishes vertebral BMAT in premenopausalanorexia nervosa (AN) patients [66]. For example, PTH administration in CR mice induces adipocyte number or adipocyte size reduction in BMAT depending on the experimental protocol [67] and erythropoietin (EPO) administration to female mice reduces BMAT with no effect on total body fat mass [68]. Leptin is noteworthy, and hypoleptinaemia is proposed to promote BMAT accumulation. A decrease in circulating leptin by pituitary removal or WAT loss in CR caused increased BMAT formation [61,69]. On the contrary, intracerebroventricular (ICV) leptin administration resulted in a BMAT decrease in rodents [70-72]. The effective loss of BMAT with exogenous leptin administration requires usage of supra-physiological dosages and it is still not estimated if a physiological amount of leptin causes BMAT changes. In conditions of a decreased oestrogen level, BMAT accumulation proceeded in spite of an increased leptin level, which shows that higher leptin alone is not sufficient to regulate BMAT $[73,74]$. In rodent CR studies, rabbits exhibited hypoleptinaemia without BMAT accumulation, while in female mice, CR caused BMAT formation but without signs of hypoleptinaemia [69]. This may lead to the conclusion that hypoleptinaemia is not necessary nor sufficient for BMAT accumulation. Peripheral administration of exogenous leptin causes a drop in BMAT differentiation [75]. Leptin, probably, causes sympathetic nervous stimulation (SNS). Sympathetic stimulation leads to an energy deficit by nutrient reservoir depletion [76]. The SNS may further trigger a release of norepinephrine and induce, through $\beta$-adrenergic receptors, lipolysis in BMAT. Some data indicate that apoptosis mayalso lead to BMAT loss as a result of leptin action [71,77].

Table 1. BMAT in various conditions [66-68,78].

\begin{tabular}{cc}
\hline Increased BMAT & Decreased BMAT \\
Ageing & Weight loss (gastric bypass) \\
Diet regimes (HFD, CR) & Oestrogen administration \\
Glucocorticoids & PTH administration (and Scl-Ab) (mice rats) \\
T1DM (mice), T2DM (mice) & EPO administration (mice) \\
Decreased oestrogen (ovariectomy-mice and rats) & Vitamin D3 administration \\
Anorexia nervosa & GH, IGF-1 \\
obesity & \\
\hline HFD—high fat diet; CR-caloric restriction; Scl-Ab—sclerotin-neutralising antibodies; EPO-erythropoietin.
\end{tabular}

\subsection{BMAT in Metabolic Disorders}

Despite its importance, the role of BMAT formation and differentiation in metabolic disorders remainsrelatively unidentified.The increase of BMAT in metabolic disease studies is higher in rodent models than in human studies. In mice with T1DM, the increase of BMAT is not equal in the skeleton;an expansion of BMAT is observed in bones of limbs, but not in the axial skeleton [42,78]. However, in humans with T1DM, changes in BMAT were not detected [78] (Table 1).

A similar observation comes from experiments on mice.In a model of T2DM (ob/ob) and mice fed a high fat diet (HFD), there was a significant increase in BMAT in both [77]. In humans with T2DM, only a minimal or no change in BMAT has been noted $[79,80]$. In obesity experiments, fed mice exhibited a higher level of BMAT expansion than obese humans $[38,81,82]$. These differences may be a result of a generally higher BMAT level in humans than in mice, relative to the body mass and also longevity of fat tissue [57,83-85].

BMAT expansion may rely on the presence of local and systemic factors regulating BMAT biogenesis and role. Clinical evidence indicates a potential role of circulating triglycerides in BMAT formation $[78,86]$. In this light, treatment with statins (decrease serum lipids levels) may potentially 'trim' BMAT. Additionally, other endocrine factors may also have a role in BMAT expansion.

\section{BMAT in Dietary Regimes}

Changes in quantity and quality of BMAT are observed in different nutritional states. Malnutrition or dietary restrictions and also HFD influence BMAT in a species-, strain- and gender-dependent manner. 


\subsection{BMAT in Obesity and High Fat Diets}

In experiments with a HFD, changes in BMAT were also dependent on a type of dietary source of fat used in the study (Table 2) [38,56,87-90]. In experiments with lard as the main calorie source, BMAT was increased, even if in some studies bone mass remained unchanged $[56,89]$. An increase of BMAT was observed in male and female C57BL/6 mice, but in females, HFD effects were dependent on the amount of food consumed; female C57BL/ 6 mice overeating during experiments: in FVB/NJ females which did not overeat the fat mass and BMAT were unchanged [88]. Difference in feeding behaviour are due to genetic background of these strains [88]. A strain-dependent effect of HFD was also noted in experiments with fish oil and saffloweroil on C57BL/6 and C3H/HeJ mice strains [89]. In $\mathrm{C} 3 \mathrm{H} / \mathrm{HeJ}$ mice, BMAT and osteoclast number in the spine were increased in fish oil fed animals [89]. In studies with fish oil and conjugated linoleic acid, a decrease in total fat content and BMAT amount was observed. Fish oil itself or vegetable oil (corn oil) did not cause a similar effect [90].

Table 2. Differences in BMAT due to different types of fat in the diet and strain of animals used in the study.

\begin{tabular}{|c|c|c|c|c|c|}
\hline Species/Strain & Age/Gender & Study Length & Type of Fat & Effects in Bones & Reference \\
\hline $\begin{array}{c}\text { Mice } \\
\text { C57BL/6J }\end{array}$ & $\begin{array}{l}12 \text { months } \\
\text { females }\end{array}$ & 6 months & $\begin{array}{l}\text { linoleic acid } \\
+ \text { fish oil } \\
\text { corn oil }\end{array}$ & $\begin{array}{c}\uparrow \mathrm{BMD}, \downarrow \mathrm{BMAT}, \downarrow \text { total fat mass } \\
\uparrow \mathrm{BMAT}\end{array}$ & {$[90]$} \\
\hline $\begin{array}{c}\text { Mice } \\
\text { C57BL/6J }\end{array}$ & $\begin{array}{l}6 \text { weeks } \\
\text { males }\end{array}$ & 12 weeks & $62 \%$ lard & $\begin{array}{l}\downarrow \text { cortical bone cross-section area, } \\
\uparrow \text { BMAT, } \downarrow \text { BMD }\end{array}$ & [87] \\
\hline $\begin{array}{l}\text { Mice } \\
\text { C57BL/6J } \\
\text { C3H-6T }\end{array}$ & $\begin{array}{l}10 \text { weeks } \\
\text { females }\end{array}$ & $\begin{array}{l}\text { sacrificed in } 12 \text { th } \\
\text { month of age }\end{array}$ & $22 \%$ fish oil & $\begin{array}{c}\uparrow \mathrm{BMAT} \text { in spine, } \downarrow \text { BMD more } \\
\text { pronounced in } 6 \mathrm{~T} \text { strain than in B6, }\end{array}$ & [89] \\
\hline \multirow{3}{*}{$\begin{array}{c}\text { Mice } \\
\text { C57BL/6J }\end{array}$} & \multirow{3}{*}{$\begin{array}{l}3 \text { weeks } \\
\text { males } \\
\text { males and } \\
\text { females }\end{array}$} & & $22 \%$ safflower oil & $\begin{array}{l}\text { prevented weight gain and bone loss } \\
\text { in spine }\end{array}$ & \multirow{3}{*}{ [38] } \\
\hline & & 12 weeks & $60 \%$ lard & $\begin{array}{c}\uparrow \mathrm{BMAT} \text { volume, } \uparrow \text { total body weight, } \\
\approx \mathrm{BMD}\end{array}$ & \\
\hline & & short term 2 weeks & $58 \%$ lard & $\uparrow \mathrm{BMAT}, \uparrow$ body weight & \\
\hline $\begin{array}{c}\text { Mice } \\
\text { C57BL/6J }\end{array}$ & $\begin{array}{l}3 \text { weeks } \\
\text { females }\end{array}$ & $3,8,17$ weeks & $\begin{array}{c}39 \% \text { lard }+ \\
6 \% \text { soybean oil }\end{array}$ & $\begin{array}{c}\uparrow \mathrm{BMAT}, \uparrow \text { body weight, } \downarrow \text { trabecular } \\
\text { bone architecture, } \downarrow \text { femoral cortical } \\
\text { bone acquisition }\end{array}$ & [88] \\
\hline $\begin{array}{l}\text { Mice FVB } \\
\text { Mice } \\
\text { C57Bl/6J }\end{array}$ & $\begin{array}{l}8 \text { weeks } \\
\text { males }\end{array}$ & 12 and 20 weeks & $6 \%$ fat from lard & $\begin{array}{c}\approx \text { BMAT, body weight, } \\
\uparrow \mathrm{BMAT} \text { volume, } \downarrow \text { BMD, } \downarrow \text { amount of } \\
\text { stem cells in bone marrow }\end{array}$ & {$[56]$} \\
\hline
\end{tabular}

The amount of BMAT was also studied in obesity and diabetes in humans. In prepubertal girls, BMAT increases with age, and is correlated with body mass and body fat [91]. In adults, increased body weight is not always associated with increased BMAT in obese and diabetic patients [92]. A positive correlation is observed between BMAT and $\mathrm{HbA1c}$, but not with HOMA-IR (marker of insulin resistance), insulin level, Pre adipocyte factor 1 (Pref-1) or leptin [92-94]. On the other hand, weight loss in clinically obese patients decreases the BMAT amount [95]. After gastric bypass, all obese patients lost weight and BMAT. Interestingly, patients with a lower content of BMAT in preoperative examination, lost less BMAT in comparison to patients with a higher BMAT, who lost more BMAT in the post-operative period. Females lost more than males, probably due to endogenous oestradiol levels [95]. However, the BMAT reduction after bariatric procedures depends on the type of procedure used [96]. In a comparison of Roux-en-Y gastric bypass (RYGB) and sleeve gastrectomy (SG) patients, greater loss of weight was observed in RYGB patients than SG. BMAT increased in SG patients in comparison to RYGB patients, probably due to the smaller weight loss in SG [96]. 


\subsection{Dietary Restrictions and BMAT}

Dietary restrictions are considered beneficial for health and longevity [97]. The impact of caloric restriction has been studied in many animal models, also in the context of bone health.

In human studies with dietary restrictions in the context of BMAT, work has focused mainly on anorexia nervosa (AN) patients, as bone quality is severely lowered and BMAT is increased and may comprise about $31 \%$ of total body adipose tissue [2,98]. The differences observed by various groups are mainly due to age and disease severity. Red to yellow marrow transition is related to the degree of nutritional deprivation [99]. In adolescent girls (mild to moderate AN), BMAT shows a strong association with age: in younger girls ( $<16$ years of age) authors observed a positive correlation between BMAT and body mass index (BMI) and bone mineral density (BMD). In older girls (>17 years of age), BMAT was inversely correlated with BMI and BMD [99]. In another study, the authors showed increased BMAT and lowered BMD in bones of the spine and hips as weight-bearing bones, and also in the whole body in adolescent patients. BMAT showed a negative association with bone strength [100]. In older AN patients (>25years of age), BMAT was also increased and BMD was lowered. It was correlated with a decreased leptin level, increased adiponectin level, and interestingly, inversely correlated with HOMA-IR factor and Pref-1 [22,101]. In this age group of AN patients, weight gain was associated with an increase in BMAT in the femur with a \% change in BMAT positively associated with a $\%$ change in leptin level and positively associated with a \% change in subcutaneous adipose tissue [101]. In severe cases of AN, the gelatinous transformation of bone marrow was noted as a sign of starvation [102]. Bone marrow biopsies of some AN patients revealed atrophy of adiposecells and loss of haematopoietic cells, which may be related to fat cell depletion due to catabolism in the tissue [103]. This symptom, however, is rare- $-0.2-4.8 \%$ of all AN patients and is usually present in young males [103]. After weight gain, the restoration of haematopoietic cells and BMAT cells was observed [103].

In animal models of caloric restriction (CR), the effect of food deprivation on BMAT is species-, strain- and gender-specific (Table 3).

Table 3. CR in animal models.

\begin{tabular}{|c|c|c|c|c|c|}
\hline Species/Strain & Age/Gender & Study Length & Type of Restriction & Effects in Bones & Reference \\
\hline $\begin{array}{l}\text { Mice } \\
\text { C57BL/6J } \\
\text { Apo-/- }\end{array}$ & $\begin{array}{l}11 \text { weeks } \\
\text { males }\end{array}$ & 4-12 weeks & $30 \% \mathrm{CR}$ & $\begin{array}{c}\downarrow \text { bone quality, } \downarrow \text { BM, } \\
\uparrow \text { adiponectin in BMAT } \\
\text { No influence of CR in apo-/- }\end{array}$ & [104] \\
\hline $\begin{array}{c}\text { Mice } \\
\text { C57BL/6J }\end{array}$ & $\begin{array}{l}3 \text { weeks } \\
\text { males }\end{array}$ & 3-9 weeks & $30 \% \mathrm{CR}$ & $\begin{array}{c}\downarrow \text { trabecular volume, leptin, } \downarrow \\
\text { osteoblast } \\
\text { number, } \uparrow \text { trabecular } \\
\text { separation, } \uparrow \text { bone resorption, } \\
\uparrow \text { BMAT }\end{array}$ & [41] \\
\hline $\begin{array}{c}\text { Mice } \\
\text { C57BL/6J }\end{array}$ & $\begin{array}{l}9 \text { weeks } \\
\text { males } \\
\text { and females }\end{array}$ & 6 weeks & $30 \% \mathrm{CR}$ & $\begin{array}{c}\text { Males: } \\
\downarrow \text { BW, } \downarrow \text { leptin, } \uparrow \text { rBMAT (tibia), } \\
\uparrow \text { adiponectin, } \\
\uparrow \text { Glucocorticoids } \\
\text { Females: } \\
\approx \mathrm{TBF}, \begin{array}{l}\text { leptin, } \uparrow \text { rBMAT } \\
\text { (tibia), }\end{array}\end{array}$ & [69] \\
\hline Rabbits & $\begin{array}{l}6 \text { weeks } \\
\text { males } \\
4 \text { weeks }\end{array}$ & 7 weeks & $30 \% \mathrm{CR}$ & $\begin{array}{c}\approx \text { adiponectin }, \downarrow \text { BW, } \downarrow \text { leptin, } \\
\quad \downarrow \text { bone quality, } \approx \text { BMAT }\end{array}$ & \\
\hline $\begin{array}{c}\text { Mice } \\
\text { C57BL/6J }\end{array}$ & $\begin{array}{l}\text { Males } \\
\text { and } \\
\text { females }\end{array}$ & 9 months & $\begin{array}{l}\text { every-other day } \\
\text { feeding }\end{array}$ & $\begin{array}{l}\uparrow \mathrm{BMAT} \text { in females, } \approx \text { mineral } \\
\text { content in long bones }\end{array}$ & [105] \\
\hline $\begin{array}{c}\text { Mice } \\
\text { C57BL/6J }\end{array}$ & $\begin{array}{l}11 \text { weeks } \\
\text { females }\end{array}$ & $\begin{array}{l}6 \text { weeks }+ \text { voluntary } \\
\text { running }\end{array}$ & $30 \% \mathrm{CR}$ & $\begin{array}{l}\downarrow \text { bone quality, } \uparrow \text { BMAT } \\
\quad \text { (femurs), } \uparrow \text { CD36 }\end{array}$ & [106] \\
\hline $\begin{array}{l}\text { Sprague- } \\
\text { Downey rats }\end{array}$ & 8 months of age & 12 months & $40 \% \mathrm{CR}$ & $\begin{array}{c}\downarrow \text { BW, } \downarrow \text {,bone quality, } \downarrow \text { leptin, } \\
\uparrow \text { rBMAT(tibia), }\end{array}$ & [107] \\
\hline $\begin{array}{l}\text { Sprague- } \\
\text { Downey rats }\end{array}$ & Males and females & $48 \mathrm{~h}$ & fasting & $\downarrow$ body mass, $\downarrow$ BMAT in tibia & [36] \\
\hline
\end{tabular}


In rabbits, a decreased adipocyte size was observed during extensive $\mathrm{CR}$ in growing animals, in mature rabbits during 30\% CR, BMAT remained unchanged [69]. In the same study, moderate $(30 \%)$ CR in mice caused an increase of BMAT deposits in the proximal tibia in males but in females the body fat was unchanged, while rBMAT increased. The authors concluded that glucocorticoids were responsible for BMAT expansion, as these hormones were increased in mice and unchanged in rabbits [69]. In growing mice (C57BL/6), 30\% of $\mathrm{CR}$ caused growth retardation, decreased bone quality (more pronounced in limb bones than in vertebrae), increased bone resorption and dramatically increased BMAT (after 9 weeks of treatment $+794 \%$ ) [41]. In short experiment in C57BL/6 and apo-/- (adiponectin knockout) mice CR negatively affected the microstructure of long bones and vertebrae of C57BL/ 6 mice but not bones of apo-/- mice [104]. Adiponectin levels in C57BL/ 6 mice was increased in all measured adipose tissue regions, suggesting that adiponectin is responsible for bone loss during CR [104]. In our experiment with long-term every-other-day feeding (effects similar to about $40 \%$ restriction), we found increased BMAT but only in female C57BL/ 6 mice [105]. In this experiment, bone mineral content measured directly in long bone ashes was unchanged [105]. Short (48h) fasting in rats caused a decrease of BMAT in the tibia but not in the vertebrae of males and females [36]. In long experiment with $40 \% \mathrm{CR}$ in mature rats increase of BMAT in limb bones was observed [107]. In old rats on CR, serum leptin was on a similar level to young (2-month-old) rats and significantly lower than age matched ad libitum(AL) fed animals [107]. Decreased calorie intake effects on bone and BMAT may be moderated by other interventions, i.e., physical exercise or osteoanabolic agent administration. In an experiment with voluntary running female mice, trabecular bone parameters were decreased in CR running animals, but BMAT in long bones in CR runners was lower than in sedentary CR mice [106]. These authors concluded that lipid storage in BMAT may be a result of different expression of fatty acid (FA) uptake during $\mathrm{CR}$ and exercise, as CD36 (marker of FA uptake) was increased in sedentary CR mice in comparison to CR runners and AL groups of animals [106]. In a study with CR and PTH administration in female mice, the effects of hormone's action was dependent on time, when PTH treatment was introduced to the study protocol. Intervention with PTH when CR was started resulted in the upregulation of osteogenic genes' expression, but not adipogenesisrelated genes-resulting in decreased number of adipocytes in BMAT. Injections with PTH, started after CR was introduced to animals, did not prevent adipogenesis, but caused a reduction of adipocyte size due to lipolysis [67].

\section{Conclusions}

In conclusion, the proper amount of BMAT is required for bone health and an increase in marrow adiposity negatively influences bone quality. Additionally, there is a link between total body fat (TBF) and BMAT. The existing data show a U-shaped association between TBF and BMAT. During conditions of high and low TBF, BMAT is elevated, and normalises with the normalisation of TBF [95]. Studies in AN patients indicate that elevated levels of preadipocyte factor-1 (Pref-1), cortisol, early B-cell factor-1 (Ebf-1) may be determinants of BMAT development [22]. However further research is needed to establish correlation between these factors and BMAT.

Author Contributions: Conceptualisation, K.P., M.T.; investigation, K.P., M.T.; resources, K.P., M.T.; writing—original draft preparation, K.P., M.T.; writing—review and editing, K.P., M.T. All authors have read and agreed to the published version of the manuscript.

Funding: This research received no external funding.

Conflicts of Interest: The authors declare no conflict of interest. 


\section{References}

1. Sulston, R.J.; Cawthorn, W.P. Bone Marrow Adipose Tissue as an Endocrine Organ: Close to The Bone? Horm. Mol. Biol. Clin. Investig. 2016, 28, 21-38. [CrossRef] [PubMed]

2. Cawthorn, W.P.; Scheller, E.L.; Learman, B.S.; Parlee, S.D.; Simon, B.R.; Mori, H.; Ning, X.; Bree, A.J.; Schell, B.; Broome, D.T.; et al. Bone Marrow Adipose Tissue Is an Endocrine Organ That Contributes to Increased Circulating Adiponectin during Caloric Restriction. Cell Metab. 2014, 20, 368-375. [CrossRef] [PubMed]

3. Youmna, K.; Scadden, D.T. Mesenchymal Cell Contributions to the Stem Cell Niche. Cell. Stem. Cell. 2015, 16, 239-253.

4. Nuttall, M.E.; Shah, F.; Singh, V.; Thomasporch, C.; Frazier, T.; Gimble, J.M. Adipocytes and the Regulation of Bone Remodeling: A Balancing Act. Calcif. Tissue Int. 2014, 94, 78-87. [CrossRef]

5. Li, Q.; Wu, Y.; Kang, K. Marrow Adipose Tissue: Its Origin, Function, and Regulation in Bone Remodeling and Regeneration. Stem. Cells Int. 2018, 7098456. [CrossRef]

6. Hausman, D.B.; Digrolamo, M.; Bartness, T.J.; Hausman, G.J.; Matrin, R.J. The Biology of White Adipocyte Proliferation. Obes. Rev. 2001, 2, 239-254. [CrossRef]

7. Tang, Q.Q.; Lane, M.D. Adipogenesis: From Stem Cell to Adipocyte. Annu. Rev Biochem. 2012, 81, 715-736. [CrossRef]

8. Ahmadian, M.; Wang, Y.; Sul, H.S. Lipolysis in Adipocytes. Int. J. Biochem. Cell. Biol. 2010, 42, 555-559. [CrossRef]

9. Hawkes, C.P.; Mostoufi-Moab, S. Fat-Bone Interaction within the Bone Marrow Milieu: Impact on Hematopoiesis and Systemic Energy Metabolism. Bone 2019, 119, 57-64. [CrossRef]

10. Rosen, E.D.; Macdougald, O.A. Adipocyte Differentiation from the Inside Out. Natrev. Mol. Cell. Biol. 2006, 7, 885-896. [CrossRef]

11. Ibrahim, M.M. Subcutaneous and Visceral Adipose Tissue: Structural and Functional Differences. Obesrev. Rev. 2010, 11, 11-18. [CrossRef]

12. Strissel, K.J.; Stancheva, Z.; Miyoshi, H.; Perfield, J.W.; Defuria, J.; Jick, Z.; Greenberg, A.S.; Obin, M.S. Adipocyte Death, Adipose Tissue Remodeling, And Obesity Complications. Diabetes 2007, 56, 2910-2918. [CrossRef]

13. Yang, H.; Youm, Y.H.; Vandanmagsar, B.; Ravussin, A.; Gimble, J.M.; Greenway, F.; Stephens, J.M.; Mynatt, R.L.; Dixit, V.D. Obesity Increases the Production of Proinflammatory Mediators from Adipose Tissue T Cells and Compromises TCR Repertoire Diversity: Implications for Systemic Inflammation and Insulin Resistance. J. Immunol. 2010, 185, 1836-1845. [CrossRef]

14. Seale, P.; Bjork, B.; Yang, W.; Kajimura, S.; Chin, S.; Kuang, S.; Scime, A.; Devarakonda, S.; Conroe, H.M.; Erdjument-Bromage, H.; et al. PRDM16 Controls A Brown Fat/Skeletal Muscle Switch. Nature 2008, 454, 961-967. [CrossRef] [PubMed]

15. Cannon, B.; Nerdegaard, J. Brown Adipose Tissue: Function and Physiological Significance. Physiol. Rev. 2004, 84, 277-359. [CrossRef] [PubMed]

16. Cypess, A.M.; Lehman, S.; Williams, G.; Tal, I.; Rodman, D.; Goldfine, A.B.; Kuo, F.C.; Palmer, E.L.; Tseng, Y.H.; Doria, A.; et al. Identification And Importance Of Brown Adipose Tissue In Adult Humans. N. Engl. J. Med. 2009, 360, 1509-1517. [CrossRef] [PubMed]

17. Ravussin, E.; Galgani, J.E. The Implication of Brown Adipose Tissue for Humans. Annu. Rev. Nutr. 2011, 31, 33-47. [CrossRef]

18. Ikeda, K.; Maretich, P.; Kajimura, S. The Common and Distinct Features of Brown and Beige Adipocytes Wn And Beige Adipocytes. Trends Endocrinol. Metab. 2018, 29, 191-200. [CrossRef] [PubMed]

19. Wang, Q.; Zhang, M.; Xu, M.; Gu, W.; Xi, Y.; Qi, L.; Li, B.; Wang, W. Brown Adipose Tissue Activation Is Inversely Related To Central Obesity And Metabolic Parameters In Adult Human. PLoS ONE 2015, 10, E0123795. [CrossRef]

20. Martínez-Fernández, L.; Fernández-Galilea, M.; Felix-Soriano, E.; Escoté, X.; González-Muniesa, P.; Moreno-Aliaga, M.J. Inflammation and Oxidative Stress. In Adipose Tissue Obesity Oxidative Stress and Dietary Antioxidants; Del Moral, A.M., García, C.M.A., Eds.; Academic Press: Cambridge, MA, USA, 2018; pp. 63-92.

21. Chechi, K.; Van Markenlichtenbelt, W.; Richard, D. Brown and Beige Adipose Tissues: Phenotype and Metabolic Potential in Mice and Men. J. Appl. Physiol. 2018, 124, 482-496. [CrossRef]

22. Fazeli, P.K.; Horowitz, M.C.; Macdougald, O.A.; Scheller, E.L.; Rodeheffer, M.S.; Rosen, C.J.; Klibanski, A.J. Marrow Fat and Bone-New Perspectives. Clin. Endocrinol. Metab 2013, 98, 935-945. [CrossRef]

23. Scheller, E.L.; Cawthorn, W.P.; Burr, A.A.; Horowitz, M.C.; Macdougald, O.A. Marrow Adipose Tissue: Trimming the Fat. Trends Endocrinolmetab 2016, 27, 392-403. [CrossRef] [PubMed]

24. Sivasubramaniyan, K.; Lehnen, D.; Ghazanfari, R.; Sobiesiak, M.; Harichandan, A.; Mortha, E.; Petkova, N.; Grimm, S.; Cerabona, F.; De Zwart, P.; et al. Phenotypic and Functional Heterogeneity of Human Bone Marrow- And Amnion-Derived MSC Subsets. Ann. N.Y. Acad. Sci. 2012, 1266, 94-106. [CrossRef] [PubMed]

25. Abdallah, B.M.; Kassem, M. New Factors Controlling the Balance between Osteoblastogenesis and Adipogenesis. Bone 2012, 50, 540-545. [CrossRef]

26. Hardouin, P.; Rharass, T.; Lucas, S. Bone Marrow Adipose Tissue: To Be or Not to Be A Typical Adipose Tissue? Front. Endocrinol. 2016, 7, 85. [CrossRef] [PubMed]

27. Ge, C.; Zhao, G.; Li, B.; Li, Y.; Cawthorn, W.P.; Macdougald, O.A.; Franceschi, R.T. Genetic Inhibition of Ppar $\gamma$ S112 Phosphorylation Reduces Bone Formation and Stimulates Marrow Adipogenesis. Bone 2018, 107, 1-9. [CrossRef]

28. Moore, S.G.; Dawson, K.L. Red and Yellow Marrow in the Femur: Age-Related Changes in Appearance at MR Imaging. Radiology 1990, 175, 219-223. [CrossRef]

29. Schellinger, D.; Lin, C.S.; Fertikh, D.; Lee, J.S.; Lauerman, W.C.; Henderson, F.; Davis, B. Normal Lumbar Vertebrae: Anatomic, Age, And Sex Variance in Subjects at Proton MR Spectroscopy-Initial Experience. Radiology 2000, 215, 910-916. [CrossRef] 
30. Meunier, P.; Aaron, J.; Edouard, C.; Vignon, G. Osteoporosis and the Replacement of Cell Populations of The Marrow by Adipose Tissue. A Quantitative Study of 84 Iliac Bone Biopsies. Clin. Orthop. 1971, 80, 147-154.

31. Blebea, J.S.; Houseni, M.; Torigian, D.A.; Fan, C.; Mavi, A.; Zhuge, Y.; Iwanaga, T.; Mishra, S.; Udupa, J.; Zhuang, J.; et al. Structural and Functional Imaging of Normal Bone Marrow and Evaluation of Its Age-Related Changes. Seminnucl. Med. 2007, 37, 185-194. [CrossRef]

32. Cornish, J.; Macgibbon, A.; Lin, J.M.; Watson, M.; Callon, K.E.; Tong, P.C.; Dunford, J.E.; Van Der Does, Y.; Williams, G.A.; Grey, A.B.; et al. Modulation of Osteoclastogenesis By Fatty Acids. Endocrinology 2008, 149, 5688-5695. [CrossRef]

33. Krings, A.; Rahman, S.; Huang, S.; Lu, Y.; Czernik, P.J.; Lecka-Czernik, B. Bone Marrow Fat Has Brown Adipose Tissue Characteristics, Which Are Attenuated with Aging and Diabetes. Bone 2012, 50, 546-552. [CrossRef] [PubMed]

34. Lindsey, R.C.; Mohan, S. Thyroid Hormone Acting Via $\operatorname{Tr} \beta$ Induces Expression of Browning Genes in Mouse Bone Marrow Adipose Tissue. Endocrine 2017, 56, 109-120. [CrossRef] [PubMed]

35. Suchacki, K.J.; Cawthorn, W.P. Molecular Interaction of Bone Marrow Adipose Tissue with Energy Metabolism. Cur. Rmolbiol. Rep. 2018, 4, 41-49. [CrossRef] [PubMed]

36. Scheller, E.L.; Khandaker, S.; Learman, B.S.; Cawthorn, W.P.; Anderson, L.M.; Pham, H.A.; Robles, H.; Wang, Z.; Li, Z.; Parlee, S.D.; et al. Bone Marrow Adipocytes Resist Lipolysis and Remodeling in Response Tobeta-Adrenergic Stimulation. Bone 2019, 118, 32-41. [CrossRef] [PubMed]

37. Styner, M.; Pagnotti, G.M.; Mcgrath, C.; Wu, X.; Sen, B.; Uzer, G.; Xie, Z.; Zong, X.; Styner, M.A.; Rubin, C.T.; et al. Exercise Decreases Marrow Adipose Tissue Through Ss-Oxidation in Obese Running Mice. J. Bone Min. Res. 2017, 32, 1692-1702. [CrossRef]

38. Doucette, C.R.; Horowitz, M.C.; Berry, R.; Macdougald, O.A.; Anunciado-Koza, R.; Koza, R.A.; Rosen, C.J. A High Fat Diet Increases Bone Marrow Adipose Tissue (MAT) But Does Not Alter Trabecular or Cortical Bone Mass in C57BL/6J Mice. J. Cell. Physiol. 2015, 230, 2032-2037. [CrossRef] [PubMed]

39. Cuminetti, V.L. Bone Marrow Adipocytes: The Enigmatic Components of the Hematopoietic Stem Cell Niche. J. Clin. Med. 2019, 8, 707. [CrossRef]

40. Lecka-Czernik, B. Marrow Fat Metabolism Is Linked to The Systemic Energy Metabolism. Bone 2012, 50, 534-539. [CrossRef]

41. Devlin, M.J.; Cloutier, A.M.; Thomas, N.A.; Panus, D.A.; Lotinun, S.; Pinz, I.; Baron, R.; Rosen, C.J.; Bouxsein, M.L. Caloric Restriction Leads to High Marrow Adiposity and Low Bone Mass in Growing Mice. J. Bone Min. Res. 2010, 25, $2078-2088$. [CrossRef]

42. Martin, L.M.; Mccabe, L.R. Type I Diabetic Bone Phenotype Is Location but Not Gender Dependent. Histo. Chem. Cell Biol. 2007, 128, 125-133. [CrossRef]

43. Poloni, A.; Maurizi, G.; Serrani, F.; Mancini, S.; Zingaretti, M.C.; Frontini, A.; Cinti, S.; Olivieri, A.; Leoni, P. Molecular and Functional Characterization of Human Bone Marrow Adipocytes. Exph. Ematol. 2013, 41, 558.E2-566.E2. [CrossRef]

44. Ma, H.T.; Ren, R.; Chen, Y.; Griffith, J.F.; Leung, P.C.; Zhang, P. A Simulation Study of Marrow Fat Effect on Bone Biomechanics. Annu. IEEE. Eng. Med. Biolsoc. 2014, 2014, 4030-4033.

45. Gurkan, U.A.; Akkus, O. The Mechanical Environment of Bone Marrow: A Review. Ann. Biomedeng. 2008, 36, 1978-1991. [CrossRef]

46. Naveiras, O.; Nardi, V.; Wenzel, P.L.; Hauschka, P.V.; Fahey, F.; Daley, G.Q. Bone-Marrow Adipocytes as Negative Regulators of the Haematopoietic Microenvironment. Nature 2009, 460, 259-263. [CrossRef]

47. Spindler, T.J.; Tseng, A.W.; Zhou, X.; Adams, G.B. Adipocytic Cells Augment the Support of Primitive Hematopoietic Cells In Vitro But Have No Effect in The Bone Marrow Niche under Homeostatic Conditions. Stem Cells Dev. 2014, 23, 434-441. [CrossRef]

48. Mirantes, C.; Passegue, E.; Pietras, E.M. Pro-Inflammatory Cytokines: Emerging Players Regulating HSC Function in Normal and Diseased Hematopoiesis. Exp. Cell Res. 2014, 329, 248-254. [CrossRef]

49. Gunaratnam, K.; Vidal, C.; Gimble, J.M.; Duque, G. Mechanisms of Palmitate-Induced Lipotoxicity in Human Osteoblasts. Endocrinology 2014, 155, 108-116. [CrossRef] [PubMed]

50. Browning, J.D.; Baxter, J.; Satapati, S.; Burgess, S.C. The Effect of Short-Term Fasting on Liver and Skeletal Muscle Lipid, Glucose, and Energy Metabolism in Healthy Women and Men. J. Lipidres 2012, 53, 577-586. [CrossRef]

51. Scheller, E.L.; Doucette, C.R.; Learman, B.S.; Cawthorn, W.P.; Khandaker, S.; Schell, B.; Wu, B.; Ding, S.Y.; Bredella, M.A.; Fazeli, P.K.; et al. Region-Specific Variation in The Properties of Skeletal Adipocytes Reveals Regulated and Constitutive Marrow Adipose Tissues. Nat. Commun. 2015, 6, 7808. [CrossRef]

52. Corre, J.; Barreau, C.; Cousin, B.; Chavoin, J.P.; Caton, D.; Fournial, G.; Penicaud, L.; Casteilla, L.; Laharrague, P. Human Subcutaneous Adipose Cells Support Complete Differentiation but Not Self-Renewal of Hematopoietic Progenitors. J. Cell Physiol. 2006, 208, 282-288. [CrossRef] [PubMed]

53. Laharrague, P.; Larrouy, D.; Fontanilles, A.M.; Truel, N.; Campfield, A.; Tenenbaum, R.; Galitzky, J.; Corberand, J.X.; Pénicaud, L.; Casteilla, L. High Expression of Leptin by Human Bone Marrow Adipocytes in Primary Culture. FASEB J. 1998, 12, 747-752. [CrossRef]

54. Hardaway, A.L.; Herroon, M.K.; Rajagurubandara, E.; Podgorski, I. Marrow Adipocyte-Derived CXCL1 and CXCL2 Contribute to Osteolysis In Metastatic Prostate Cancer. Clin. Exp. Metastasis. 2015, 32, 353-368. [CrossRef] [PubMed]

55. Liu, L.F.; Shen, W.J.; Ueno, M.; Patel, S.; Kraemer, F.B. Characterization of Age-Related Gene Expression Profiling in Bone Marrow and Epididymal Adipocytes. BMC Genom. 2011, 12, 212. [CrossRef] [PubMed] 
56. Tencerova, M.; Figeac, F.; Ditzel, N.; Taipaleenmaki, H.; Nielsen, T.K.; Kassem, M. High-Fat Diet-Induced Obesity Promotes Expansion of Bone Marrow Adipose Tissue and Impairs Skeletal Stem Cell Functions in Mice. J. Bone Min. Res. 2018, 33, $1154-1165$. [CrossRef]

57. Trudel, G.; Payne, M.; Madler, B.; Ramachandran, N.; Lecompte, M.; Wade, C.; Biolo, G.; Blanc, S.; Hughson, R.; Bear, L.; et al. Bone Marrow Fat Accumulation After 60 Days of Bed Rest Persisted 1 Year After Activities Were Resumed Along with Hemopoietic Stimulation: The Women International Space Simulation for Exploration Study. J. Appl. Physiol. 2009, 107, 540-548. [CrossRef] [PubMed]

58. Zhang, K.; Wang, C.; Chen, Y.; Ji, X.; Chen, X.; Tian, L.; Yu, X. Preservation of High-Fat Diet-Induced Femoral Trabecular Bone Loss Through Genetic Target of TNF-Alpha. Endocrine 2015, 50, 239-249. [CrossRef] [PubMed]

59. Wang, C.; Tian, L.; Zhang, K.; Chen, Y.; Chen, X.; Xie, Y.; Zhao, Q.; Yu, X. Interleukin-6 Gene Knockout Antagonizes High-FatInduced Trabecular Bone Loss. J. Mol. Endocrinol. 2016, 57, 161-170. [CrossRef]

60. Tavassoli, M.; Marrow Adipose Cells. Histochemical Identification of Labile and Stable Components. Arch. Pathol. Lab. Med. 1976, 100, 16-18.

61. Menagh, P.J.; Turner, R.T.; Jump, D.B.; Wong, C.P.; Lowry, M.B.; Yakar, S.; Rosen, C.J.; Iwaniec, U.T. Growth Hormone Regulates the Balance Between Bone Formation and Bone Marrow Adiposity. J. Bone Min. Res. 2010, 25, 757-768. [CrossRef]

62. Iwaniec, U.T.; Turner, R.T. Failure to Generate Bone Marrow Adipocytes Does Not Protect Mice from Ovariectomy-Induced Osteopenia. Bone 2013, 53, 145-153. [CrossRef]

63. Syed, F.A.; Oursler, M.J.; Hefferanm, T.E.; Peterson, J.M.; Riggs, B.L.; Khosla, S. Effects of Estrogen Therapy on Bone Marrow Adipocytes in Postmenopausal Osteoporotic Women. Osteoporosint 2008, 19, 1323-1330. [CrossRef] [PubMed]

64. Wei, W.; Dutchak, P.A.; Wang, X.; Ding, X.; Wang, X.; Bookout, A.L.; Goetz, R.; Mohammadi, M.; Gerard, R.D.; Dechow, P.C.; et al. Fibroblast Growth Factor 21 Promotes Bone Loss by Potentiating the Effects of Peroxisome Proliferator-Activated Receptor $\Gamma$. Proc. Natl. Acad. Sci. USA 2012, 109, 3143-3148. [CrossRef] [PubMed]

65. Vande Berg, B.C.; Malghem, J.; Lecouvet, F.E.; Devogelaer, J.P.; Maldague, B.; Houssiau, F.A. Fat Conversion of Femoral Marrow in Glucocorticoid-Treated Patients: A Cross-Sectional and Longitudinal Study with Magnetic Resonance Imaging. Arthritis. Rheum. 1999, 42, 1405-1411. [CrossRef]

66. Polineni, S.; Resulaj, M.; Faje, A.T.; Meenaghan, E.; Bredella, M.A.; Bouxsein, M.; Lee, H.; Macdougald, O.A.; Klibanski, A.; Fazeli, P.K. Red and White Blood Cell Counts Are Associated with Bone Marrow Adipose Tissue, Bone Mineral Density, and Bone Microarchitecture in Premenopausal Women. J. Bone Min. Res. 2020, 35, 1031-1039. [CrossRef] [PubMed]

67. Maridas, D.E.; Rendina-Ruedy, E.; Helderman, R.C.; Demambro, V.E.; Brooks, D.; Guntur, A.R.; Lanske, B.; Bouxsein, M.L.; Rosen, C.J. Progenitor Recruitment and Adipogenic Lipolysis Contribute to The Anabolic Actions of Parathyroid Hormone on The Skeleton. FASEB J. 2019, 33, 2885-2898. [CrossRef]

68. Suresh, S.; Alvarez, J.C.; Dey, S.; Noguchi, C.T. Erythropoietin-Induced Changes in Bone and Bone Marrow in Mouse Models of Diet-Induced Obesity. Int. J. Mol. Sci. 2020, 21, 1657. [CrossRef]

69. Cawthorn, W.P.; Scheller, E.L.; Parlee, S.D.; Pham, H.A.; Learman, B.S.; Redshaw, C.M.; Sulston, R.J.; Burr, A.A.; Das, A.K.; Simon, B.R.; et al. Expansion of Bone Marrow Adipose Tissue During Caloric Restriction Is Associated with Increased Circulating Glucocorticoids and Not with Hypoleptinemia. Endocrinology 2016, 157, 508-521. [CrossRef] [PubMed]

70. Hamrick, M.W.; Della Fera, M.A.; Choi, Y.H.; Hartzell, D.; Pennington, C.; Baile, C.A. Injections of Leptin into Rat Ventromedial Hypothalamus Increase Adipocyte Apoptosis in Peripheral Fat and in Bone Marrow. Cell Tissue Res. 2007, 327, 133-141. [CrossRef] [PubMed]

71. Ambati, S.; Li, Q.; Rayalam, S.; Hartzell, D.L.; Della-Fera, M.A.; Hamrick, M.W.; Baile, C.A. Central Leptin Versus Ghrelin: Effects on Bone Marrow Adiposity and Gene Expression. Endocrine 2010, 37, 115-123. [CrossRef]

72. Bartell, S.M.; Rayalam, S.; Ambati, S.; Gaddam, D.R.; Hartzell, D.L.; Hamrick, M.; She, J.X.; Della-Fera, M.A.; Baile, C.A. Central (ICV) Leptin Injection Increases Bone Formation, Bone Mineral Density, Muscle Mass, Serum IGF-1, and the Expression of Osteogenic Genes in Leptin-Deficient Ob/Ob Mice. J. Bone Min. Res. 2011, 26, 1710-1720. [CrossRef]

73. Ainslie, D.A.; Morris, M.J.; Wittert, G.; Turnbull, H.; Proietto, J.; Thorburn, A.W. Estrogen Deficiency Causes Central Leptin Insensitivity and Increased Hypothalamic Neuropeptide Y. Int. J. Obes. Relat. Metab. Disord. 2001, 25, 1680-1688. [CrossRef]

74. Martin, R.B.; Chow, B.D.; Lucas, P.A. Bone Marrow Fat Content in Relation to Bone Remodeling and Serum Chemistry in Intact and Ovariectomized Dogs. Calcif. Tissue Int. 1990, 46, 189-194. [CrossRef]

75. Scheller, E.L.; Song, J.; Dishowitz, M.I.; Soki, F.N.; Hankenson, K.D.; Krebsbach, P.H. Leptin Functions Peripherally to Regulate Differentiation of Mesenchymal Progenitor Cells. Stem Cells 2010, 28, 1071-1080. [CrossRef] [PubMed]

76. Peirce, V.; Carobbio, S.; Vidal-Puig, A. The Different Shades of Fat. Nature 2014, 510, 76-83. [CrossRef]

77. Hamrick, M.W.; Della-Fera, M.A.; Choi, Y.H.; Pennington, C.; Hartzell, D.; Baile, C.A. Leptin Treatment Induces Loss of Bone Marrow Adipocytes and Increases Bone Formation in Leptin-Deficient Ob/Ob Mice. J. Bone Min. Res. 2005, 20, 994-1001. [CrossRef]

78. Slade, J.M.; Coe, L.M.; Meyer, R.A.; Mccabe, L.R. Human Bone Marrow Adiposity Is Linked with Serum Lipid Levels Not T1-Diabetes. J. Diabetes Complicat. 2012, 26, 1-9. [CrossRef] [PubMed]

79. Schwartz, A.V. Marrow Fat and Bone: Review of Clinical Findings. Front. Endocrinol. 2015, 6, 40. [CrossRef] 
80. Baum, T.; Yap, S.P.; Karampinos, D.C.; Nardo, L.; Kuo, D.; Burghardt, A.J.; Masharani, U.B.; Schwartz, A.V.; Li, X.; Link, T.M. Does Vertebral Bone Marrow Fat Content Correlate with Abdominal Adipose Tissue, Lumbar Spine Bone Mineral Density, and Blood Biomarkers in Women with Type 2 Diabetes Mellitus? J. Magn. Reson. Imaging 2012, 35, 117-124. [CrossRef]

81. Bredella, M.A.; Torriani, M.; Ghomi, R.H.; Thomas, B.J.; Brick, D.J.; Gerweck, A.V.; Rosen, C.J.; Klibanski, A.; Miller, K.K. Vertebral Bone Marrow Fat Is Positively Associated with Visceral Fat and Inversely Associated With IGF-1 In Obese Women. Obesity 2011, 19, 49-53. [CrossRef] [PubMed]

82. Bredella, M.A.; Lin, E.; Gerweck, A.V.; Landa, M.G.; Thomas, B.J.; Torriani, M.; Bouxsein, M.L.; Miller, K.K. Determinants of Bone Microarchitecture and Mechanical Properties in Obese Men. J. Clin. Endocrinol. Metab. 2012, 97, 4115-4122. [CrossRef] [PubMed]

83. Casamassima, F.; Ruggiero, C.; Caramella, D.; Tinacci, E.; Villari, N.; Ruggiero, M. Hematopoietic Bone Marrow Recovery after Radiation Therapy: MRI Evaluation. Blood 1989, 73, 1677-1681. [CrossRef]

84. Spalding, K.L.; Arner, E.; Westermark, P.O.; Bernard, S.; Buchholz, B.A.; Bergmann, O.; Blomqvist, L.; Hoffstedt, J.; Näslund, E.; Britton, T.; et al. Dynamics of Fat Cell Turnover in Humans. Nature 2008, 453, 783-787. [CrossRef] [PubMed]

85. Berry, D.C.; Stenesen, D.; Zeve, D.; Graff, J.M. The Developmental Origins of Adipose Tissue. Development 2013, 140, 3939-3949. [CrossRef] [PubMed]

86. Patsch, J.M.; Burghardt, A.J.; Yap, S.P.; Baum, T.; Schwartz, A.V.; Joseph, G.B.; Link, T.M. Increased Cortical Porosity in Type 2 Diabetic Postmenopausal Women with Fragility Fractures. J. Bone Min. Res. 2013, 28, 313-324. [CrossRef] [PubMed]

87. Fujita, Y.; Watanabe, K.; Maki, K. Serum Leptin Levels Negatively Correlate with Trabercular Bone Mineral Density in High- Fat Diet-Induced Obesity Mice. J. Musculoskelet. Neuronal Interact. 2012, 12, 84-94. [PubMed]

88. Develin, M.J.; Robbins, A.; Cosman, M.N.; Moursi, C.A.; Cloutier, A.M.; Louis, L.; Van Vliet, M.; Conlon, C.; Bouxsein, M.L. Differential Effects of High Fat Diet and Diet-Induced Obesity on Skeletal Acquisition in Female C57BL/6 Vs.FBV/NJ Mice. Bone Rep. 2016, 88, 204-214.

89. Bonnet, N.; Somm, E.; Rosen, C.J. Diet and Gene Interactions Influence the Skeletal Response to Polyunsaturated Fatty Acids. Bone 2014, 68, 100-107. [CrossRef]

90. Halade, G.V.; Rahman, M.; Williams, P.J.; Fernandes, G. Conbination of Conjugated Linoleic Acid with Fish Oil Prevents Age-Associated Bone Marrow Adiposity in C57Bl/6J Mice. J. Nutr. Biochem. 2011, 22, 459-469. [CrossRef]

91. Newton, A.L.; Hanks, L.J.; Davis, M.; Casazza, K. The Relationship among Total Body Fat, Bone Mineral Content and Bone Marrow Adipose Tissue in Early-Pubertal Girls. Bonekey. Rep. 2013, 315. [CrossRef]

92. De Araújo, I.M.; Salmon, C.E.; Nahas, A.K.; Nogueira-Barbosa, M.H.; Elias, J., Jr.; De Paula, F.J. Marrow Adipose Tissue Spectrum in Obesity and Type 2 Diabetes Mellitus. Eur. J. Endocrinol. 2017, 176, 21-30. [CrossRef]

93. De Paula, F.J.; De Araújo, I.M.; Carvalho, A.L.; Elias, J., Jr.; Salmon, C.E.; Nogueira-Barbosa, M.H. The Relationship of Fat Distribution and Insulin Resistance with Lumbar Spine Bone Mass in Women. PLoS ONE 2015, 10, E0129764. [CrossRef]

94. Yu, E.W.; Greenblatt, L.; Eajazi, A.; Torriani, M.; Bredella, M.A. Marrow Adipose Tissue Composition in Adults with Morbid Obesity. Bone 2017, 97, 38-42. [CrossRef]

95. Blom-Høgestøl, I.K.; Mala, T.; Kristinsson, J.A.; Hauge, E.M.; Brunborg, C.; Gulseth, H.L.; Eriksen, E.F. Changes in Bone Marrow Adipose Tissue One Year After Roux-En-Y Gastric Bypass: A Prospective Cohort Study. J. Bone Min. Res. 2019, 34, 1815-1823. [CrossRef]

96. Bredella, M.A.; Greenblatt, L.; Eajazi, A.; Torriani, M.; Yu, E.W. Effects of Roux-En-Y Gastric Bypass and Sleeve Gastrectomy on Bone Mineral Density and Marrow Adipose Tissue. Bone 2017, 95, 85-90. [CrossRef]

97. Golbidi, S.; Daiber, A.; Korac, B.; Li, H.; Essop, M.F.; Laher, I. Health Benefits of Fasting and Caloric Restriction. Currdiab. Rep. 2017, 17, 123. [CrossRef]

98. Bredella, M.A.; Fazeli, P.K.; Daley, S.M.; Miller, K.K.; Rosen, C.J.; Klibanski, A.; Torriani, M. Marrow Fat Composition in Anorexia Nervosa. Bone 2014, 66, 199-204. [CrossRef] [PubMed]

99. Ecklund, K.; Vajepeyam, S.; Mulkern, R.V.; Feldman, H.A.; O’Donnell, J.M.; Divasta, A.D.; Gordon, C.M. Bone Marrow Fat Content In 70 Adolescent Girls with Anorexia Nervosa: Magnetic Resonance Imaging and Magnetic Resonance Spectroscopy Assessment. Pediatr. Radiol. 2017, 47, 952-962. [CrossRef] [PubMed]

100. Singhal, V.; Tulsiani, S.S.; Campoverde, K.J.; Mitchell, D.M.; Slattery, M.; Schorr, M.; Miller, K.K.; Bredella, M.A.; Misra, M.; Klibanski, A. Impaired Bone Strength Estimates at The Distal Tibia and Its Denerminants In Adolescence with Anorexia Nervosa. Bone 2018, 106, 61-68. [CrossRef] [PubMed]

101. Fazelli, P.K.; Faje, A.T.; Bredella, M.A.; Polineni, S.; Russel, S.; Resulaj, M.; Rosen, C.J.; Klibanski, A. Changes in Marrow Adipose Tissue with Short-Term Changes in Wiegth In Premenopausal Women With Anorexia Nervosa. EJ. Endocrinol. 2019, 180, 189-199.

102. Abella, E.; Feliu, E.; Granada, I.; Millá, F.; Oriol, A.; Ribera, J.M.; Sánchez-Planell, L.; Berga, L.I.; Reverter, J.C.; Rozman, C. Bone Marrow Changes in Anorexia Nervosa Are Correlated with The Amount of Weight Loss and Not with Other Clinical Findings. Am. J. Clinpathol. 2002, 118, 582-588. [CrossRef] [PubMed]

103. Hariz, A.; Hamdi, M.S.; Boukhris, I.; Boujelbène, N.; Azzabi, S.; Khalfallah, N. Gelatinous Transformation of Bone Marrow in A Patient with Anorexia Nervosa: An Uncommon but Reversible Etiology. Am. J. Case Rep. 2018, 19, 1449-1452. [CrossRef] [PubMed]

104. Zhu, J.; Liu, C.; Jia, J.; Zhang, C.; Yuan, W.; Leng, H.; Xu, Y.; Song, C. Short-Term Caloric Restriction Induced Bone Loss in Both Axial and Appendicular Bones by Increasing Adiponectin. Ann. N.Y. Acad. Sci. 2020, 1474, 1-14. [CrossRef] [PubMed] 
105. Piotrowska, K.; Zgutka, K.; Kupnicka, P.; Chlubek, D.; Pawlik, A.; Baranowska-Bosiacka, I. Analysis of Bone Mineral Profile After Prolonged Every-Other-Day Feeding in C57BL/6J Male and Female Mice. Biol. Trace Elem. Res. 2020, 194, 177-183. [CrossRef] [PubMed]

106. Mcgrath, C.; Sankaran, J.S.; Misaghian-Xanthos, N.; Sen, B.; Xie, Z.; Styner, M.A.; Zong, X.; Rubin, J.; Styner, M. Exercise Degrades Bone in Caloric Restriction, Despite Suppression of Marrow Adipose Tissue (MAT). J. Bone Min. Res. 2020, 35, 106-115. [CrossRef]

107. Duque, G.; Saedi, A.; Rivas, D.; Miard, S.; Ferland, G.; Picard, F.; Gaudreau, P. Differential Effects of Long-Term Caloric Restriction and Dietary Protein Source on Bone and Marrow Fat of The Aging Rat. J. Gerontol. A Biol. Sci. Med. Sci. 2020, 75, 1-6. [CrossRef] [PubMed] 